Article

\title{
False Shades of Green: The Case of Brazilian Amazonian Hydropower
}

\section{James Randall Kahn ${ }^{1,2, *}$, Carlos Edwar Freitas ${ }^{2,3}$ and Miguel Petrere ${ }^{4,5}$}

1 Environmental Studies Program/Economics Department, Washington and Lee University, Holekamp Hall 206, Lexington, VA 24450, USA

Department of Fishery Science, Universidade Federal do Amazonas, Av. Rodrigo Otávio 3000, Manaus, AM 69077-000, Brazil; E-Mail: freitasc50@gmail.com

3 Department of Biology, Washington and Lee University, Lexington, VA 24450, USA

4 Programa de Pós-graduação em Diversidade Biológica e Conservação (PPGDBC),

Centro de Ciências e Tecnologias para a Sustentabilidade (CCTS),

Universidade Federal de São Carlos (UFSCar), Rod. João Leme dos Santos, km 110 - Sorocaba, São Paulo 18052-780, Brazil; E-Mail: mpetrerejr@gmail.com

5 UNISANTA, Programa de Pós-Graduação em Sustentabilidade de Ecossistemas Costeiros e Marinhos, Rua Oswaldo Cruz, 277 (Boqueirão), Santos (SP) 11045-907, Brazil

* Author to whom correspondence should be addressed; E-Mail: kahnj@wlu.edu; Tel.: +1-540-458-8036, +1-540-460-1421, +55-92-8114-9305.

Received: 30 June 2014; in revised form: 15 August 2014 / Accepted: 1 September 2014 / Published: 16 September 2014

\begin{abstract}
The Federal Government of Brazil has ambitious plans to build a system of 58 additional hydroelectric dams in the Brazilian Amazon, with Hundreds of additional dams planned for other countries in the watershed. Although hydropower is often billed as clean energy, we argue that the environmental impacts of this project are likely to be large, and will result in substantial loss of biodiversity, as well as changes in the flows of ecological services. Moreover, the projects will generate significant greenhouse gas emissions from deforestation and decay of organic matter in the reservoirs. These emissions are equivalent to the five years of emissions that would be generated by gas powered plants of equivalent capacity. In addition, we examine the economic benefits of the hydropower in comparison to new alternatives, such as photovoltaic energy and wind power. We find that current costs of hydropower exceed alternatives, and the costs of costs of these alternatives are likely to fall substantially below those of hydropower, while the environmental damages from the dams will be extensive and irreversible.
\end{abstract}


Keywords: Amazonian dams; biodiversity; fishery dynamics; extinction; environmental policy; energy policy

\section{Introduction}

Perspectives and paradigms of thought change slowly. In the United States, both citizens and politicians cling to the view that cheap fossil fuels are necessary for economic growth. A corresponding pattern exists in Brazil, where hydroelectric power is linked to the health of the economy. Currently, $85 \%$ of electric energy is generated by hydropower in Brazil, with the hydroelectric potential of southern Brazil almost completely utilized [1]. As Brazil looks to its future, it continues to follow this hydroelectric path, looking for a source of energy that can cover an equivalent proportion of future electric energy needs. As a consequence, it has planned an extensive series of 58 projects (in addition to 11 in place (more than 12,000 MW) and six under construction (more than 19,000 MW)). These dams will have catastrophic environmental consequences, in addition to causing displacement and suffering for indigenous and traditional populations. Moreover, the system of Amazonian hydroelectric projects is not even the best way of meeting Brazil's future energy needs when examined from the perspective of more narrowly defined economic costs and benefits. The purpose of this paper is to discuss the economic, environmental, and social costs of the proposed hydroelectric system in the hopes of developing a better understanding of the consequences of a proposed plan that most Brazilians accept as both inevitable and desirable. Section 2 of the paper will present an environmental economics paradigm for examining large-scale conversions of pristine ecosystems into development projects. Section 3 summarizes the extent of the proposed projects and the environmental impacts associated with them. Section 4 looks at narrowly defined economic costs associated with the generation of electricity, both hydropower and alternatives. Section 5 presents our conclusions.

Brazil's economic growth, even before the 20th century, has been tightly linked to the development of hydropower. The prevalence of hydropower originates in the topography of Brazil, where plateaus and mountains can be found very close to the coast, permitting the development of hydroelectric facilities very close to coastal population centers. During most of the 20th century, the availability of both coal and oil was limited and there were few alternatives except for hydropower. In 2007, even with Brazil becoming a net exporter of petroleum, $85 \%$ of electrical generation in Brazil was provided by hydropower, with only nine percent provided by conventional thermal plants [1]. We can see that in the past, the focus on hydropower was, not just a convenience, but a necessity. Hydropower and electricity became synonymous in Brazil. Following this old line of thinking, President Roussef's administration has adopted and expanded on the plans of previous administrations to expand hydropower, but planning it in the Amazon region, which is ill-suited for this activity. The plans call for an increase in hydroelectric power capacity of more than 35,000 MW, principally by damming rivers in Amazonia, an area of questionable economic and environmental appropriateness for hydropower development. This does not include all the dams under construction or proposed by other Amazonian countries (412 in total [2]) for which the impacts on the Andes-Amazonas connectivity were addressed by [3]. More than 12,000 square kilometers of forest would be inundated by these 
proposed projects within Brazil [3] (Since estimates of some of the proposed sites have not yet been made, these numbers and resulting calculations can be viewed as a lower bound approximation of the totals associated with planned projects.), Attention must also focus on watershed fragmentation [4]. It is understandable that Brazil has equated hydrological resources with electric power. However, with the advent of new technologies for generating electricity, the sacrifice of these large tracts of Amazonia rainforest and the fragmentation of the watershed are not only unnecessary, but will hurt Brazil in the future.

\section{The Economics of Irreversible Investments}

John Krutilla's seminal article, Conservation Reconsidered [5] changed the way many people thought about the idea of resource scarcity, moving away from traditional focus on exhaustible natural resources such as coal. Instead, he highlighted the need to conserve unique natural environments, such as free flowing rivers, forests with high levels of biodiversity, and environments with unique cultural significance. Krutilla's work continued and was followed by a set of papers that expanded on this theme [6-9]. Although they did not label it as such, these authors argued for a precautionary principle in terms of development projects that could irreversibly alter the natural environment in the area of a development project. They examined projects, such as the Trans-Alaska Pipeline, hydroelectric dams in the Snake River system, mining projects, and the development of ski resorts.

This analysis was based on the idea that the benefits of development will decline over time, and the environmental costs of the development are likely to increase over time. As stated by Fisher et al. ([6], p. 609).

....it will in general be optimal to refrain from development even when indicated by a comparison of current benefits and costs if, in the relatively near future, "undevelopment" or disinvestment, which are impossible, would be indicated.

In other words, a decision based on the relationship between costs and benefits over the short run could lead to future damages that are both irreversible and sufficiently high relative to initial benefits, causing us to regret our initial decision. It is very interesting to note that the paper in which this statement was made was specifically examining a hydroelectric project in the Hell's Canyon area of the Snake River (Columbia River system, NW United States).

Project benefits decline for a number of reasons, such as the depreciation of the investment and the development of alternative technologies that have lower private and social costs. Another factor specifically related to dams is that sedimentation [10] will reduce the storage capacity of the reservoir, and diminish the capacity of the power plants to generate electricity. Finally, global climate change is predicted to diminish the average flow of the rivers in the southeast of the Amazon region (the location of most of the proposed dams) and will increase the variability of the flows [11]. Both the sedimentation and the change in the flows of the rivers will reduce the capacity of the dams to generate electrical power.

The environmental costs increase over time for a variety of reasons. As more natural environments are lost to population growth and economic development, the opportunity cost of the lost environmental and cultural benefits from the degraded development sites become greater. There are 
two policy implications of these time paths. The first is that development is a "now or never" phenomenon. If benefits are declining over time and costs are increasing over time, the present value of the stream of net benefits will never be larger than if development starts immediately. Any delay will lower the present value of the stream of net benefits. On the other hand, there is a great danger associated with miscalculation. If the evaluation is made based on a difference between present benefits and present costs that is perceived to be larger than it actually is, then it is even more likely that true costs will rise to exceed true benefits in the future by a great margin. This argues for caution and taking the time to ascertain costs and benefits with a great deal of certainty before embarking on a path that might be associated with a disastrous outcome in the future.

The irreversibility of future costs is what really drives the need for present caution. There are three types of irreversibility that need to be considered. The first is physical irreversibility. For example, if a species becomes extinct, it is physically impossible to restore the species. The second is economic irreversibility. Although it may be physically possible to restore an area of land that is contaminated by radioactive or toxic waste, the cost of this restoration may be so high that restoration cannot take place. Finally, there is indirect irreversibility [12]. Indirect irreversibility arises in the complex relationships that characterize ecological and environmental systems. Although the direct impact of the action may be reversible, the direct impact sets into motion a series of changes, which are irreversible. For example, the introduction of a new predator species into a lake could result in a drastic decline or extinction of the smaller fish that graze on algae. This could lead to algal blooms and associated eutrophication, creating anoxic zones, and further declines in fish populations. Even if the grazing species does not become extinct and the predator species is removed, the eutrophication of the lake could be irreversible as populations of the grazer species may not be able to recover in the anoxic waters of the lake.

Ansar et al. [13] talk of diminished project benefits from large dams and other projects because cost estimates tend to be biased downward as the estimates are based on the "inside view" of the advocates of the project. They suggest an alternative approach, reference class forecasting, a tool developed by Kahnemann and Lovallo [14] Reference class forecasting is based on an "outside" view by analyzing past relevant projects to better estimate costs of a proposed project. This furthers the arguments of Krutilla and his contemporaries in arguing for caution when initial estimates indicate that the benefits of development are greater than the cost. Both arguments indicate that the appearance of positive net present value is likely to be an illusion.

It is important to note that this area of the literature makes this argument for caution while using a maximization criterion of economic efficiency, involving the discounting of future costs and benefits. Extending this analysis to ethical and sustainability criteria makes the case for caution even more compelling.

\section{Past Experiences with Hydroelectric Power in Amazonia}

The first hydropower project completed in Amazonia in 1975 was Coaracy Nunes, which had a reservoir surface area of $23 \mathrm{~km}^{2}$. This was followed in 1977 by another small project, Curuá Una, with $30 \mathrm{MW}$ of capacity and inundating $72 \mathrm{~km}^{2}$. In 1984, the first high capacity project was initiated (Tucuruí $\left(8370 \mathrm{MW}, 2850 \mathrm{~km}^{2}\right)$ ) and then, in 1989, the Balbina project was implemented, a low 
capacity but geographically large project $\left(250 \mathrm{MW}, 4,438 \mathrm{~km}^{2}\right)$ [15] This area represents the high water level, as measured by satellite, by INPE, the Brazilian space agency. There have been considerable variations in published estimates of the area of the Balbina reservoir. for example, [16] cite the area as $2360 \mathrm{~km}^{2}$. This may be due to different measurement methods or because the reservoir fluctuates so much between the high water and low water seasons. New dams have been added in the intervening years for a total of eleven projects with a combined capacity of 19,278 MW and 11,054 km² of inundated area [3]. There are six dams under construction with a capacity of $8045 \mathrm{MW}$, with four of the five dams (data are not available for the Dardanelos) inundating $1137 \mathrm{~km}^{2}$ [3]. However, this does not include Belo Monte, where construction has recently begun. This single dam has a capacity of $11,233 \mathrm{MW}$ with a flooded area of $660 \mathrm{~km}^{2}$. Fifty-eight additional dams are planned for the future. Capacity data is available for 51 of these sites, totaling 34,596 MW, with the reservoirs covering approximately $12,000 \mathrm{~km}^{2}$.

Currently, the bulk of Brazilian hydroelectric plants currently are concentrated in the Southeast and South regions of the country (Table 1), although substantial development of hydropower in the Amazon watershed has begun.

Table 1. Hydroelectric power generation installed in 2004.

\begin{tabular}{ccc}
\hline Region & Power $(\mathbf{M W})$ & Proportion of total (\%) \\
\hline North & 7524 & 11 \\
Northeast & 10,386 & 15 \\
Southeast & 23,304 & 34 \\
South & 18,885 & 27 \\
Center-West & 8899 & 13 \\
Total & 68,999 & 100 \\
\hline
\end{tabular}

Source: Empresa de Pesquisa Energética (EPE), [17].

The Brazilian government recognizes that despite the high hydroelectric potential of Amazon basin, this area is characterized by environmental constraints [18]. The environmental constraints cited by the Brazilian government are actually bureaucratic definitions, listed without ranking their relative importance preference. These constraints consist of the presence of cities, areas with high demographic density, and protected areas (National Forests, National Parks, Indigenous Areas, Environmental Protection Areas, Biological Reserves, Sustainable Development Reserves), and interference with pristine rivers. Other factors that form constraints are the size of the inundated area, land value, and potential interference with highways or railways. Employing only these criteria, the Brazilian government estimates that $38 \%$ of the hydroelectric potential of the Amazon basin, evaluated in 77,058 MW, could be classified as without environmental constraints [18]. However, "without environmental constraints" does not mean without extraordinary losses if these areas were deforested or degraded.

A first problem is the use of these criteria in an unstudied region. The sparse and fragmented studies of aquatic biodiversity developed in the headwaters of Amazonian rivers indicate a potential great loss of unknown species that are endemic to these areas [19]. The inadequacy of this evaluation becomes more evident, as the plan assumes that entire sub-basins of the Rio Negro basin are completely without environmental constraints (Table 2), even though these regions are probably the most pristine and least studied area in the Amazon basin. The flaw in this assumption is intensified by the high level of 
endemism observed in aquatic fauna. In addition, we will demonstrate important global climate change impacts associated with the emission of $\mathrm{CO}_{2}$ and $\mathrm{CH}_{4}$ both above and below the dams.

Table 2. Hydroelectric potential (MW) of the Amazon sub-basins with proportion of environmental constraints.

\begin{tabular}{cccc}
\hline Sub-basin & $\begin{array}{c}\text { With environmental } \\
\text { constraints }\end{array}$ & $\begin{array}{c}\text { Without environmental } \\
\text { constraints }\end{array}$ & Total \\
\hline Tapajós & 6875 & 17,841 & 24,716 \\
Xingu & 5681 & 17,114 & 22,795 \\
Madeira & 13,144 & 1556 & 14,700 \\
Trombetas & 1491 & 4745 & 6236 \\
Negro & 0 & 4184 & 4184 \\
Jari & 318 & 1373 & 1691 \\
Branco & 419 & 660 & 1079 \\
Paru & 820 & 118 & 938 \\
Oiapoque & 0 & 250 & 250 \\
Purus & 0 & 213 & 213 \\
Maecuru & 0 & 161 & 161 \\
Nhamundá & 0 & 110 & 110 \\
Uatumã & 75 & 0 & 75 \\
Total & 28,823 & 48,325 & 77,148 \\
\hline
\end{tabular}

Source: Empresa de Pesquisa Energética (EPE, Energy Research Corporation, Ministry of Mines and Energy, Brazil) [18].

Second, there is a concentration of the planned impoundments for some sub-basins, such as the Tapajós, Xingu, Madeira, and Trombetas Rivers, where almost $90 \%$ of the estimated potential (Table 2) is planned for implementation. But these areas exhibit the highest degree of environmental constraints determined by the criteria established by the Brazilian government (Table 2). In addition to the high level of endemic fish species, these sub-basins are characterized by the presence of large indigenous areas and units of conservation. In reality, the government will change the boundaries of these conservation areas to permit the construction of these planned hydroelectric dams, rendering the environmental constraints completely toothless. For example, the Instituto Humanitas Unisinos [20] reports that, on 26 June 2012, the government of Brazil announced in the O Diário Oficial da União (the official register of the union) the intent to change the borders of eight areas of environmental protection to allow the implementation of the hydroelectric projects at the Complexo de Tapajós in the State of Pará and Santo Antonio in the State of Rondônia.

The environmental impacts associated with hydroelectric projects fall into three major categories. These consist of impacts on global climate change, local environmental impacts, and basin-wide environmental impacts. In addition, there are important social impacts.

Global climate change impacts consist of the release of the carbon stored in the terrestrial and riverine ecosystems. Since much of this organic material decays in an anoxic environment, a great deal of the organic matter is converted into methane, which has a much greater impact on global climate change than carbon dioxide. It is important to note that the literature tends to focus on the emissions associated with the loss of forests, but the conversion of shallow river and lake areas to deep reservoir 
areas will result in the loss of a great deal of biomass of macrophyte plants with resulting methane and carbon dioxide emissions.

Local environmental impacts consist of impacts associated with the loss of forest, the drowning of riverine ecosystems, negative downstream impacts and fragmentation of local ecosystems. All of these combine to lower the production of ecological services in the region of the dam, with implications for both ecosystems and human communities.

System-wide ecological effects relate to changes in the entire region that single dams and groups of dams could create, such as the cascade of reservoirs planned for the Tietê and Tocantins Rivers. It is important to understand that system-wide impacts of a system of dams will be greater than the sum of the impacts of the local impacts of the individual dams. A crucial question could be the loss of connectivity in the Amazon basin and its implications [21].

\subsection{Greenhouse Gas Emissions and Global Climate Impacts}

Hydropower is often referred to as clean energy because a perception exists that there are no emissions because there are no smokestacks. However, this is not the case because there is emission of gases from the surface of reservoir, as well as downstream emissions. The construction of dams to create any type of reservoir, will result in the death of the terrestrial plants inundated by the reservoir, which stops the assimilation of carbon dioxide $\left(\mathrm{CO}_{2}\right)$ by photosynthesis, resulting in the loss of a sink for atmospheric $\mathrm{CO}_{2}$. In addition, bacteria will decompose the organic carbon stored in the plants and soils, converting it to $\mathrm{CO}_{2}$ and methane $\left(\mathrm{CH}_{4}\right)$, which are then released to the atmosphere.

The early discussions of greenhouse gas emissions from reservoirs [22,23] pointed out that greenhouse gas production per unit of power generated (e.g., in $\mathrm{kWh}$ ) will depend on the amount of organic carbon flooded to create the electricity. For example, reservoirs that flood large areas to produce few $\mathrm{kWh}$, such as those built in flat areas, would produce more greenhouse gases per $\mathrm{kWh}$ than reservoirs built in canyons where little area is flooded and large amounts of electricity are produced. Note that this type of canyon is not found in the Brazilian Amazon.

In this context, Balbina reservoir could be considered the worst example, because the facility only produces $105.9 \mathrm{kWh}$ per hectare of surface area. Moreover, there was no removal of the forest before the reservoir was inundated and there was an enormous amount of organic carbon stored in the submerged trees. In addition to the greenhouse gas emissions from the water surface of reservoir, downstream emissions from hydroelectric dams can be significant, originating from the rapid depressurization the water that flows through the turbines [24,25].

The proposed plan for new hydroelectric projects will inundate over $12,000 \mathrm{~km}^{2}$ of rainforest Fearnside [26], calculates a mean estimate of 157 tons of carbon per hectare of rainforest, which is equivalent to 576.6 tons of carbon dioxide (This is roughly the same magnitude as the estimate of Cederberg et al. [27] of $612 \pm 212$ tons of $\mathrm{CO}_{2}$ per ha), This extrapolates to roughly 692 million metric tons of carbon dioxide that will be liberated through the inundation of the rainforest by the proposed reservoirs. The global warming implications of these 692 million tons of carbon dioxide can be better understood by comparing it to the annual emissions from the burning of fossil fuels in Brazil, which in 2010 was 453.87 million metric tons [28] In other words, the carbon that would be released from these $12,000 \mathrm{sq} \mathrm{km}$ of rain forest is roughly equal to 1.52 times the annual emissions of fossil fuel use in 
Brazil. Brazil would have to reduce its emissions from fossil fuels by $10 \%$ for a period of 15 years just to offset the carbon released by the inundation of these forests by the reservoirs.

Further climate change impacts are created as some of the carbon converts to methane before passing to the atmosphere. Kemenes et al. [25] measured the methane entering the atmosphere from the reservoir above the Balbina hydroelectric dam, and in the river below. They find this to be a carbon dioxide equivalent of $557 \mathrm{Gg}, \mathrm{C}$ or 557,000 metric tons per year (We use the per acre estimates of Kemenes et al. [25] in our calculations). If one extrapolates this to the proposed plan by scaling on surface area of the proposed reservoirs, this implies that the carbon dioxide equivalent of the methane emissions from the proposed hydropower projects would equal 3.146 million metric tons per year. It is difficult to predict total emissions over time, because [24] found non-linear relationships in a small reservoir in Guyana, with roughly ten times the emissions in the tenth year as in the first. The Kemenes et al. study [25] was roughly 15 years after the closure of the Balbina dam. If we used this estimate as the mean (most likely an underestimate) over thirty years, it would imply total methane emissions of roughly 93 million metric tons, or that the methane emissions are roughly $20 \%$ of the annual emissions from fossil fuels.

The combined impacts of the methane and carbon emissions of the proposed reservoirs sum to the equivalent of 785 million tons of carbon dioxide equivalents, or 1.73 times the 2010 emissions from fossil fuel combustion in Brazil. This would be equal to the emissions of 5.19 years of electricity generation from the equivalent capacity of gas powered thermal plants or 3.7 years of oil powered thermal plants. In order to offset the total emissions $\left(\mathrm{CH}_{4}+\mathrm{CO}_{2}\right)$ from the proposed reservoirs, Brazil would need to reduce its emissions from fossil fuels by $10 \%$ per year over seventeen years.

Since the proposed reservoirs have roughly the same total area as the reservoirs in operation and under construction, the combined effect of the whole hydroelectric system in Brazil is roughly 1570 million metric tons, or 3.46 times the 2010 emissions from fossil fuels. The remainder of the analysis will only focus on the proposed dams, but it can easily be converted to include both those in operation and under construction by multiplying by a factor of two. The reader should also keep in mind that these proposed dams do not include the full extent of hydropower potential in the Amazon watershed, as defined by the government of Brazil. It only includes those facilities for which plans have been developed. Moreover, it does not include the dams proposed by other countries such as Bolivia, Peru, Columbia and Ecuador.

Another way of thinking of the emissions from the proposed hydroelectric plants is to think of the total global damages caused by the dams. Estimates summarized by the United Nations Intergovernmental Panel on Climate Change (IPCC) [29] place the damages associated with a ton of carbon at between 10 and 200 dollars per ton, while the Stern report [30] identifies a mean value of $\$ 85$ per ton. Choosing the Stern estimate (which is in the middle of the range suggested by IPCC [29]), the 785 million tons of carbon dioxide translate into global damages of 66.8 billion dollars. At an estimated cost of construction of 62 billion dollars (using average per W values for the few dams without published estimates), the global climate change cost of the proposed hydroelectric projects exceeds the estimated construction costs, even when a very modest estimate of the costs per ton of carbon dioxide is used.

What portion of this cost will Brazil have to pay? This is a question that can be answered in many ways. First, look at the direct damages of global warming to Brazil. The exacerbated El Niño Southern Oscillation (ENSO) cycle generated by global warming leads to increased drought in the Northeast, 
greater floods and greater dry periods in the hydrological cycle of the Amazon River system and shrinkage of the Amazonian Rainforest. The shrinkage of the Amazonian forest leads to less recycling of the rainfall, and further shrinkage as lower rainfall stimulates forest transformation into grasslands along the edge of the rainforest. It also diminishes rainfall in important agricultural regions in the south of Brazil, as well as Argentina and Paraguay [31,32]. Furthermore, Rio de Janeiro, much of which is built upon fill, is very vulnerable to sea level rise, as are other Brazilian coastal cities.

In addition, it is quite possible that there will be a direct monetary cost associated with this carbon loss. Depending on the international climate change treaty, which will eventually be negotiated and ratified, there could be economic incentives associated with carbon emissions and land use. It is quite possible that these new emissions associated with the loss of the forest and methane emissions will count against the "cap" that Brazil would face in a "cap and trade" system, or would generate a tax liability in a treaty that focused on carbon taxes. Moreover, the new emissions associated with the reservoirs could disqualify Brazil from participating in a system such as the proposed program, Reducing emissions from deforestation and forest degradation REDD+, because the hydroelectric reservoirs are new sources of deforestation.

Local Environmental and Social Impacts:

In addition to those impacts related to global climatic changes, there are local impacts associated with what Rosenberg et al. [33] term "landscape destruction" resulting in social, economic, and health consequences [34]. We define local environmental and social impacts as those that occur in the vicinity of the dam and reservoir, whether they are above or below the dam. Environmental impacts are primarily caused by the following phenomena associated with the dams.

1. Blockage of the flow of sediments, particularly in white water systems, such as the Rio Madeira, Rio Purus, and Rio Jurua;

2. Moderation of the pulse of the river (in some places as much as a $15 \mathrm{~m}$ variation in levels between the high and low water seasons);

3. Blockage of the migration of fish;

4. Reduction in oxygen levels both above and below the dams;

5. Fragmentation of the aquatic ecosystem.

Social impacts are primarily caused by the following phenomena:

1. Displacement of rural and indigenous communities, affecting their culture and way of life;

2. Loss of access to ecological services.

The blockage of the sediments will create enormous environmental impacts. The two largest tributaries of the Amazonas River, Solimões, and Madeira have their headwaters in the newly formed lands of Andean areas. Steep terrain and young lithologies make the Andes an important source of sediments to the lower reaches of the Amazon basin [35]. The predictable annual flood of the plains adjacent to river is the key for this ecosystem $[35,36]$ and changes in the timing of the flooding and in the amount of sediments could result in dramatic and unpredictable effects.

One normally associates a dam's moderating impact on the flow of water as a benefit, lessening the negative impacts of both floods and droughts. However, the pulse of the rivers in the Amazon are not the result of extreme conditions, but occur naturally over the year in conjunction with the annual 
fluctuation in rainfall and the dynamics associated with large rivers backing up smaller rivers. Again, individual organisms and aquatic ecosystem have evolved to take advantage of the pulse of the river. For example, many fish species spend the high water period in the várzea and return to the river channels in the low water, when the várzea is dry land. Many events for individual organisms (e.g., migration, reproduction, metamorphosis) are linked to the river pulse. The elimination of this pulse by the dams can destroy signals that trigger reproduction, and other life cycle events, potentially affecting the recruitment of species that have economic or subsistence value in addition to their ecological importance. The reproductive season of these species is synchronized with hydrological cycle to permit the use of the rich environment of floodplain by larvae and young fish. An alteration on this process could affect the recruitment as suggested by [37] in the match-mismatch hypothesis. Again, one would expect the elimination of the pulse of the river to lead to local extinction of species.

The third type of impact, the blockage of the migration of species could also have huge impacts. The reproductive success of some species of Amazonian catfish, such as piramutaba (Brachyplatystoma vaillantii) and dourada (B. rousseauxii), depends of the ability of adults to reach the headwaters of tributaries that arise in pre-Andean areas. The fragmentation of these rivers by the construction of dams could have serious detrimental effects on these populations [38]. Moreover, the aquatic ecosystem consists of a series of lakes that are connected to the rivers in the high water system and isolated from the rivers in the low water periods. Different species move back and forth between the lakes and the rivers with the pulse of the river. The moderation of the pulse of the river below the dams will permanently isolate many of these lakes from the river, losing the connectivity essential for the life cycles of these organisms. This already has been observed in the Tucurui reservoir [39] and is expected to lead to extensive extinction at the local level in the areas in which new hydroelectric projects will be established.

The problem with oxygen depletion is relatively self-explanatory. The decay of the tremendous load of organic material in the reservoirs will remove a great deal of oxygen from a system that is already low in oxygen because of the ambient temperatures. This creates problems both above and below the dam and is expected to result in the loss of species with less tolerance to low oxygen conditions, with associated impacts on other species through trophic cascading.

The problem of fragmentation of ecosystems has come up both in terms of blocking the migration within a river, and breakage of connections between the river and lakes. Fragmentation is also generated by the reservoir itself, isolating terrestrial communities on one side of the reservoir from the other.

The net impact of all these factors would be greatly increased rates of local extinctions. Wearn et al. [40] and Rangel [41] define an "extinction debt" that is generated by existing deforestation, particularly in the "arc of deforestation" in the southern part of the Brazilian Amazon. The idea of extinction debt is that only a small part of the extinction associated with the existing loss of habitat in the Amazon has already occurred, although this loss in habitat will ensure that many more species become completely or locally extinct in these degraded areas over time. The idea of extinction debt is very important in that the extinctions and loss in biodiversity caused by the hydroelectric reservoirs is not added on top of the current extinction and biodiversity losses from deforestation, but the full extent when the debt comes due. In addition, there will be more deforestation in the future from other sources (mining, industrial agriculture, cattle ranching, timbering, urbanization, etc.), which will lead to even more deforestation and more extinction. 
The hydroelectric projects will cause important social damages as well [42]. The World Commission on Dams [43] cites displacement of local populations as the most significant social cost associated with hydroelectric projects in the developing world. They define two types of displacement, direct displacement and displacement of sources of income and subsistence. Direct displacement refers to the inundation of traditional lands of the communities in the region, forcing them to migrate to a new location, which is likely to be less suitable than the location that they left. This was observed in Tucurui, where people were forced to settle in the less fertile terra firme (upland rainforest) as the rich várzea soil was permanently inundated. In some cases, the refugees from hydroelectric facilities are forced onto land that is already occupied, generating conflict and increased competition for resources. Significant psychological stress can accompany this type of displacement. The loss of income and means of subsistence, while not a direct displacement, can be even more painful, as families on the edge of economic survival fall below the minimum level. With the loss of nutrients and the fragmentation of the aquatic ecosystems, it is certain that fishery resources will fall significantly in the region, diminishing the only source of protein for the people in the vicinity of the hydroelectric projects. In addition, the blockage of nutrients can have impacts on other extractive activities as well as agriculture. Sediment islands are eroding due to lack of replenishment, and there is indication that important species such as açai (Euterpe oleracea) and buriti (Mauritia flexuosa) are suffering from lack of nutrients downstream of the Tucurui project Farmers and extractivists are having to purchase nutrients. This impact has caused many extractivists and farmers to flee the area and move to the state capital of Belem [44]. Moreover, the opening of these regions by access road could lead to immigration from other areas, leading to more deforestation, and conflicts between the original residents and the newcomers. Moreover, concentrations of imported workers who arrive without their families often lead to social problems at the access city or community, such as prostitution, drugs and crime in general.

\subsection{System Wide Environmental Impacts}

The loss of nutrients, the fragmentation of the aquatic ecosystem and other local environmental impacts also have system-wide impacts as the scale and the number of the projects are quite large. As is most often the case with multiple sources of environmental stress, the combined stress is greater than the sum of the individual stresses. This point is emphasized by Finer and Jenkins [3] who state that the impacts of hydroelectric dams on the Amazon basin should be considered in a broad perspective, including the planned projects of other Amazonian countries, such as Bolivia, Colombia, Ecuador and Peru. The fragmentation of Amazonian rivers arising in the pre-Andean areas could result in an even more severe nutrient impoverishment of the rivers because the mountains and associated uplands are the main source of the waterborne sediments that form the basis for the high primary productivity observed in the Amazonian floodplains.

Given the existing sources of stress to the Amazonian ecosystem (deforestation, global climate change, biodiversity loss, etc.), the scale of the Brazilian hydroelectric plans, and the planned hydroelectric activities in other Amazonian countries, it is not an overstatement to say that the entire ecosystem is at risk. The acceptance of this risk is not necessary as alternatives (principally wind power and solar power) are a lower cost alternative at present, and the cost advantage is likely to grow over time. 


\section{Economics of Hydropower and Alternatives}

The first step in the comparison of hydropower with alternatives is to discuss the costs and benefits associated with electric production from the different sources of generation. It is important to realize that all megawatts of generation are not equal, and some are better for base load generation and some are better for peak load generation. The most important characteristics of generation for base load are a low average cost and resistance to interruptions. For example, ignoring other social costs, coal is a good fuel for base load generation. One can stockpile coal on the site, and with the exception of scheduled maintenance or accident, there is no reason why the plant would have to shut down in the middle of operations. On the other hand, a coal-fired plan cannot be brought on line quickly, so it is not a good source of peak load generation.

Cost is less of a factor in meeting peak load demand, with the most important characteristic being that it could be brought on-line (and off-line) very quickly. Natural gas is a very good fuel for peak load for this reason, and depending on the cost it could also be a good fuel for base load. Reiterating, cost and resistance to interruption are the primary characteristics for a good base load fuel, while ease of start-up is the most important characteristic for a peak load source of generation.

The other reason that all megawatts of capacity are not created equal is the difference between nameplate capacity and effective capacity. Nameplate capacity is the capacity of a generation system when all factors are ideal, while the effective capacity is the average capacity, which takes into account reductions in capacity when conditions are not ideal. For example, fluctuations in river flows, the intensity of sunlight or velocity of the wind could reduce the effective capacity of hydropower, photovoltaic cells and wind power, respectively. Another factor is distance from the market where the energy will be consumed. The transmission of electricity over power lines generates a loss of electricity as resistance converts electric energy into heat energy. Table 3 contains a list of effective capacities for alternative sources of electrical generation for the United States. An additional reduction of the effective capacity of Amazonian hydropower may occur in the future as the flow of the rivers of the planned projects diminishes in response to an overall reduction in humidity in the region as a result of global climate change [45]. To our knowledge, such a table has not been calculated for Brazil.

Table 3. Effective capacity estimates for the USA.

\begin{tabular}{ccc}
\hline Technology & Range of effective capacity estimates & Average effective capacity \\
\hline Geothermal & $0.76-0.98$ & 0.86 \\
New hydropower & $0.33-0.49$ & 0.42 \\
Existing hydropower & $0.39-0.69$ & 0.51 \\
Photovoltaic & $0.16-0.28$ & 0.22 \\
Wind & $0.29-0.49$ & 0.39 \\
Offshore wind & $0.35-0.49$ & 0.42 \\
Wave & $0.14-0.39$ & 0.27 \\
Tidal & $0.29-0.49$ & 0.34 \\
Combined cycle (gas/coal) & $\mathrm{n} / \mathrm{a}$ & 0.8 \\
Coal & $\mathrm{n} / \mathrm{a}$ & 0.85 \\
Biomass (average all types) & $0.43-0.90$ & 0.72 \\
\hline
\end{tabular}


With the capacity factors in mind, and the need to meet both base load and peak load demands for electricity, one can elaborate the benefits and costs associated with hydropower. The primary benefit of hydropower is that is can provide a significant contribution to base load demand and also make contributions to peak load demand. For example, a hydro-facility could run some of its turbines constantly for base load and direct water through the remaining turbines to generate additional electricity during peak load periods. Unlike coal plants, there is very little start-up cost or delay in initiating additional generation for peak load demand. However, we will show that hydropower has a higher cost of generation than alternatives, such as wind power and solar power.

The economic costs of the hydroelectric facility are frontloaded, dominated by the costs of construction of the dam. Once the facility becomes operational, the economic benefits of the power generation tend to be front loaded as well, declining rapidly over time. There are two primary reasons for this. First, the capacity of the reservoir erodes as it fills with sediments. The stated MW capacity of the dam does not represent the actual capacity as the reservoir begins to fill with sediment, reducing the amount of water that can be stored (in general, this is not included when calculating effective capacity). Dams could be designed to reduce the retention of sediments, but this possibility remains a potential issue. Secondly, the costs per kilowatt-hour of alternative technologies will fall over time, eroding the economic cost savings associated with the hydropower. For example, the cost of rooftop solar panels in 2012 was $1 \%$ of the cost in 1977 [47].

We will start our examination with the construction cost per watt of capacity of hydroelectric production in the Amazon. The total construction cost for each existing plant and the estimated construction cost for planned projects and projects under construction from Ecologia em Ação (ECOA) [3] were used to calculate average cost per watt for existing projects, projects under construction and planned projects. Note that we estimate cost per watt of total capacity, not effective capacity, which is always below the boiler plate capacity. The costs were converted into 2011 dollars and averaged to yield the average cost within each category. These averages per watt of capacity came to US\$1.96 for existing plants, \$3.01 for plants under construction, and 1.97 for planned projects. Note that the costs for effective capacity may be much higher than the calculations above. For example, the estimated cost per watt at the Belo Monte dam (under construction) is 1.69 per watt. However, if one accepts the argument by Miesen and Hubert [1] that the hydroelectric facility will only operate at $10 \%$ capacity during the low water season this would imply an actual cost of US\$ 6.9 per watt of effective capacity (Ansar et al. [13] note that their statistical analysis shows an average cost of $\$ 2.80$ per watt of boiler plate capacity, but that this average is skewed downward by North American dams, which tend to be cheaper). Alternatively one could recalculate the cost per watt of effective capacity using the low estimate (since this area has such a fluctuation in the flow of rivers) and the average estimate for new hydropower in the table above. With the low estimate of 0.33 effective capacity, the cost would be US\$ 5.12 per watt of effective capacity, and US\$ 4.02 using the average capacity estimate from the above table. For the average cost of planned hydroelectric projects (US\$ 1.97) the corresponding figures would be 5.96 and 4.69. Note that another reduction in capacity occurs with transmission in power lines. ICF [48] estimates that for conventional lines, it is as high as $20 \%$ per $1000 \mathrm{~km}$. The straight line distance (Calculated using the "ruler tool" of Google Earth) from the Belo Monte project to various coastal cities are Rio de Janeiro $(2300 \mathrm{~km})$, Salvador $(1700 \mathrm{~km})$, Brasilia $(1500 \mathrm{~km})$, and Fortaleza $(1400 \mathrm{~km})$. The straight line distance between the cluster of dams proposed for southern 
Mato Grosso state are Rio de Janeiro $(2300 \mathrm{~km})$, Salvador $(1700 \mathrm{~km})$, Brasilia $(1500 \mathrm{~km})$, and Fortaleza $(1400 \mathrm{~km})$. Note that at $1000 \mathrm{~km}$ of distance, the effective capacity would diminish by $20 \%$ due to transmission. For the average estimate of the effective capacity of new hydropower, the effective capacity would be reduced to 0.33 and for the low estimate it would be reduced to 0.26 . With $2000 \mathrm{~km}$ of transmission distance, the effective capacity of a dam diminishes by $36 \%$, putting the average estimate of effective capacity at 0.26 and the low estimate at 0.21 . These transmission losses should be kept in mind when comparing hydropower with alternative technologies, as photovoltaic generation is generally located within the urban area (rooftops, parking lots, etc.) and wind power in Brazil would generally be located within $50-100 \mathrm{~km}$ of urban areas, since it is the coast and shallow offshore areas that are the best wind areas.

In addition to the impact of diminished capacity, the cost figures for planned projects and projects under construction are likely to increase significantly for two reasons. First, the indigenous groups to be displaced are physically occupying the construction site at places such as the Belo Monte site [49], delaying the projects with their protests. Second, the workers at some of the construction sites are engaged in prolonged strikes, demanding better wages [50]. Both of these factors are likely to make future construction much higher than the estimates, although at this point it is not possible to make a prediction about these potential cost increases. Furthermore, the statistical analysis of Ansar et al. [13] shows that most cost estimates for big projects, such as dams, underestimate the final cost of production by a significant amount, often as much as $100 \%$.

Table 4 provides a comparison of the cost of effective capacity for hydropower, wind power, and photovoltaic power. Other sources of energy, such as concentrated solar power and gasification of waste move prove to be the lowest cost alternatives in the future, but our analysis will focus on wind power and photovoltaic as they are the alternatives that are most contributing to new capacity at the current time. Brazil has been identified as an area with high wind power and high solar power potential, with investments accelerating in these sources of power [51,52]. The most recent costs per megawatt and effective capacity estimates are contained in first and second data columns, with the calculation of cost of effective capacity in the fourth data column. The next column contains reasons why effective capacity may change in the future, followed by estimates of these changes. The last two columns contain projected future cost change and likely future costs per watt of effective capacity.

Table 4 reveals photovoltaic power to be more cost effective than hydropower. The range of estimates for hydropower is US\$ 4.00 to 7.92 per watt, while photovoltaic is calculated at $\$ 2.60$ to 5.0. This means that the lower bound estimate of photovoltaic is lower than the corresponding estimate for hydropower by $35 \%$ and the upper bound for photovoltaic is lower by $38 \%$. When other factors that are likely to change effective capacity and future costs are considered the intervals change to 8.51 to 20.6 dollars per effective watt capacity for hydropower and 1.62 to 4.00 for photovoltaic, a very large cost advantage to photovoltaic. Furthermore, photovoltaic has the advantage of being able to handle peak load demands (daytime air conditioning) in Brazil, and does not require the use of additional land (it can be installed on buildings and in parking lots).

A similar comparison for wind power shows the cost advantage over hydropower, but slightly less so than photovoltaic. Neither of these comparisons incorporates the argument of Ansar et al. [13], that the internal estimates of costs of potential hydropower projects are likely to be significantly lower than the costs, which will be experienced when the project begins. 
Table 4. Current and expected future cost per $\mathrm{W}$ of effective capacity.

\begin{tabular}{|c|c|c|c|c|c|c|c|}
\hline Generation type & $\begin{array}{c}\text { Cost Per W of } \\
\text { Capacity } \\
\text { (US\$) } \\
\end{array}$ & $\begin{array}{c}\text { Effective } \\
\text { Capacity } \\
\text { (from Table 3) } \\
\end{array}$ & $\begin{array}{c}\text { Cost Per W of } \\
\text { Effective Capacity } \\
\text { (Current Costs) }\end{array}$ & $\begin{array}{l}\text { Reason for Change } \\
\text { In Effective Capacity }\end{array}$ & $\begin{array}{l}\text { Change in } \\
\text { Effective } \\
\text { Capacity }\end{array}$ & $\begin{array}{c}\text { Future Cost Change } \\
\text { and Reason }\end{array}$ & $\begin{array}{c}\text { Likely Future } \\
\text { Costs Per W of } \\
\text { Effective Capacity }\end{array}$ \\
\hline Hydro power & 1.96 to $3.09^{\mathrm{a}}$ & $0.3-0.49$ & $4.0-7.92$ & - & - & $\begin{array}{l}\text { Increase, but hard to } \\
\text { measure (increase in } \\
\text { construction costs) }\end{array}$ & - \\
\hline- & - & - & - & Seasonality of rainfall ${ }^{\mathrm{d}}$ & -0.05 & - & - \\
\hline- & - & - & - & Sedimentation & Not available & - & - \\
\hline- & - & - & - & $\begin{array}{l}\text { Change in river flow } \\
\text { (deforestation) }^{\mathrm{e}}\end{array}$ & -0.4 & - & - \\
\hline- & - & - & - & $\begin{array}{l}\text { Change in river flows } \\
\text { (global climate change) }\end{array}$ & Not available & - & - \\
\hline \multirow[t]{2}{*}{-} & - & - & - & Transmission line losses ${ }^{\mathrm{f}}$ & -0.2 to -0.36 & - & - \\
\hline & \multicolumn{4}{|c|}{ Net effective capacity (not including sedimentation and climate change): } & & - & 8.51 to 20.6 \\
\hline photovoltaic & $0.80^{\mathrm{c}}$ & 0.16 to 0.28 & 2.8 to 5.0 & - & - & - & \\
\hline- & - & - & - & Online storage & $\begin{array}{l}0.32 \text { to } 0.4 \text { based } \\
\text { on onsite storage }^{b}\end{array}$ & $\begin{array}{c}\text { Fall to } 0.64 \text { with } \\
\text { expansion (doubling) } \\
\text { of capacity }^{\mathrm{g}}\end{array}$ & $\begin{array}{c}\text { With storage: } \\
1.6 \text { to } 2 \\
\text { w/o storage } \\
2.25 \text { to } 4\end{array}$ \\
\hline- & - & - & - & - & - & - & - \\
\hline windpower & 1.50 to $2.50^{\mathrm{c}}$ & 0.29 to 0.49 & 3.06 to 8.6 & - & - & - & - \\
\hline- & - & - & - & $\begin{array}{l}\text { Bigger blades (more effective } \\
\text { at lower wind velocity) }\end{array}$ & +0.1 & - & 2.75 to 7.74 \\
\hline
\end{tabular}

Sources: ${ }^{\mathrm{a}}$ ECOA et al. [3]; ${ }^{\mathrm{b}}$ USDOE [53]; ${ }^{\mathrm{c}}$ USDOE [54]; ${ }^{\mathrm{d}}$ Miesen and Hubert [1]; ${ }^{\mathrm{e}}$ Stickler et al. [55]; ${ }^{\mathrm{f}}$ ICF [48]; ${ }^{\mathrm{g}}$ US Department of Energy [47]. 
It should be noted that an energy policy that stimulates both photovoltaic and wind power is more efficient that stimulating either alone, because wind power tends to be more available at night, and solar power more available during the day. This implies that the peak load/base load issues become less important as the two sources complement each other in their peak availability and base load coverage.

In summary, the current situation is that the cost of a watt of capacity for hydropower is slightly higher in comparison to wind and photovoltaic. Moreover, both the wind power and photovoltaic costs are declining rapidly, and if present trends continue, the cost differential will grow over time. Within ten years they will be less than $50 \%$ of the cost of hydropower. The comparison of hydropower with alternatives conforms to the discussion by Arrow and Fisher [8]. The technological innovation in alternatives that we are already observing will diminish the long-term benefits of the proposed hydroelectric projects in the Amazon.

\section{Conclusions}

A major policy decision must be made which will shape the future of the Amazon ecosystem, as the planned hydropower projects will have strong and irreversible impacts on the ecosystem and on communities in the region. It is clear that the ecosystem of the entire watershed will be altered in a manner that is much greater than simply the loss of forest. Most importantly, the flow of nutrients will be halted, the annual pulse of the rivers drastically modified, and there will be substantial fragmentation of the ecosystem. Extinctions (mostly local, but some global) will follow, as will other systematic modifications of the extent and quality of the linked forest and aquatic ecosystems. In addition, there are important greenhouse gas emissions from the organic matter to be flooded by the reservoirs. Although we have not done a complete cost-benefit analysis or a complete environmental impact statement, we have highlighted both the environmental damages and the economic costs of basing Brazil's energy future on extensive damming of Amazonian rivers, synthesizing the research results of the scientific and economic literature. Both economic theory and the recent developments in alternative energy technologies suggest that the current cost advantage of wind generation and photovoltaic cells will continue to increase in the future, leaving hydropower at a higher and higher relative cost. Wind generation, photovoltaic power, and other alternatives (biofuels, concentrated solar power, gasification of wastes, etc.) will exhibit increasing efficiency and declining costs over time. Moreover, sedimentation and changes in water flow regimes due to global climate change will imply that the actual capacity of the hydroelectric facilities will be much less than the stated capacity. Longterm environmental effects are likely to fundamentally damage ecosystems, and there is no economic justification for installing more hydropower capacity.

The Amazon forest and watershed are a Brazilian national treasure and a source of ecological services at the local, national and global level. Current thought tends to focus on the terrestrial aspects of the ecosystem because of its importance to global climate change, but the aquatic side is equally important or perhaps even more important because the health of the forest depends on the pulse of the river. A whole scale conversion of the ecosystem should not be considered without further study, particularly when the economic benefits of the hydroelectric facilities are likely to be negative in the short run and are certain to be even more costly in the long run. Moreover, the environmental damages will compound over time and for the most part, are irreversible. This study should not only consider 
the ecological impacts, but should compare the costs of alternative energy on a region-by-region basis in Brazil. Just as Pacala and Socolow [56] argued that reductions in greenhouse gas emissions could be accomplished by "wedges" of reduction from a wide variety of existing technologies, future Brazilian demand for energy can be met by "wedges" of alternative generation technology. One technology does not have to provide for the total increase in demand, but a combination of photovoltaic, biomass, waste-to-energy, concentrated solar power, tidal power, and other alternatives can substitute for environmentally destructive hydropower in the Amazon watershed.

Although there is a lot of impetus behind the "conventional wisdom" that hydropower is the only way to meet Brazil's future energy needs, conventional wisdom is based on past experiences and often on errant assumptions. The acceptance of immense damages to the ecosystem, based on current assumptions and an overly simplified view of ecological and economic relationships, can be avoided.

\section{Acknowledgments}

We would like to thank Peter Grajzl and three anonymous reviewers for helpful comments.

\section{Author Contributions}

All authors contributed to all sections, reviewing each other's work, offering suggestions, finding important references, and so on. Kahn took the lead on the economics and Freitas and Petrere took the lead on the ecology and hydrology.

\section{Conflicts of Interest}

The authors declare no conflict of interest.

\section{References}

1. Miesen, P.; Hubert, J. Renewable Energy Potential of Brazil; Global Energy Network Institute: San Diego, CA, USA, 2010.

2. Little, P.E. Megaprojects in the Amazon Region: A geopolitical and socio-environmental analysis with proposals of better government for the Amazon. Executive Summary, 2014, 1-96. Available online: http://dar.org.pe/archivos/publicacion/145_megaproyectos_ingles_final.pdf (accessed on 3 July 2014).

3. ECOA (Ecologia em Ação). International Rivers and Fundacion Proteger, Dams in Amazonia. Available online: http://www.dams-info.org/en (accessed on 10 August 2012).

4. Finer, M.; Jenkins, C.N. Proliferation of hydroelectric dams in the Andean Amazon and implications for Andes-Amazon connectivity. PLoS One 2012, 7, e35126, doi:10.1371/journal.pone.0035126.

5. Krutilla, J. Conservation reconsidered. Am. Econ. Rev. 1967, 57, 777-778.

6. Arrow, K.J.; Lind, R.C. Uncertainty and the evaluation of public investment decisions. Am. Econ. Rev. 1970, 60, 364-378.

7. Fisher, A.C.; Krutilla, J.; Cicchetti, C.J. The economics of environmental preservation: A theoretical and empirical analysis. Am. Econ. Rev. 1972, 62, 605-619.

8. Krutilla, J.; Fisher, A.C. The Economics of Natural Environments; Resources for the Future: Washington, DC, USA, 1985. 
9. Arrow, K.J.; Fisher, A.C. Environmental preservation, uncertainty, and irreversibility. Q. J. Econ. 1975, 88, 312-319.

10. Filizola, N.; Guyot, J.L. Fluxo de sedimentos em suspensão nos rios da Amazônia. Revista Brasileira de Geociências 2011, 41, 566-576. (In Portuguese)

11. Espinoza Villar, J.C.; Guyot, J.L.; Ronchail, J.; Cochonneau, G.; Filizola, N.; Fraizy, P.; Labat, D.; Oliveira, E.; Ordoñez, J.J.; Vauchel, P. Contrasting regional discharge evolutions in the Amazon basin (1974-2004). J. Hydrol. 2009, 375, 297-311.

12. Kahn, J.; O’Neil, R. Ecological interaction as a source of economic irreversibility. South. Econ. J. 1999, 66, 381-402.

13. Ansar, A.; Flyvbjerg, B.; Budzier, A.; Lunn, D. Should we build more large dams? The actual costs of hydropower megaproject development. Energy Policy 2014, 69, 43-56.

14. Kahneman, D.; Lovallo, D. Timid choices and bold forecasts: A cognitive perspective on risk taking. Manag. Sci. 1993, 39, 17-31.

15. FUNCATE-INPE-ANEEL, Mapeamento por satélite das áreas inundadas por reservatórios de hidrelétricas brasileiras. Relatório do Convênio FUNCATE/INPE/ANEEL; Unpublished government report; National Institute for Space Research (INPE): Sao Jose dos Campos, SP, Brazil, 2000. (In Portuguese)

16. Sá, A.A.; Brilha, J.; Rocha, D.; Couto, H.; Rabano, I.; Medina, J.; Gutierrez-Marco, J.C.; Cachao, M.; Valerio, M. Geoparque Arouca. Geologia e Património Geológico, 1st ed.; Câmara Municipal de Arouca: Arouca, Portugal, 2008; Volume 1, p. 127. (In Portuguese)

17. Empresa de Pesquisa Energética(EPE)/ Ministério de Minas e Energia.(Brasil), Balanço Energético Nacional 2005-Ano Base 2004. Rio de Janeiro. 2005. http://livroaberto.ibict.br/bitstream/1/527/1/ Balan\%C3\%A7o\%20energ\%C3\%A9tico\%20Nacional\%202005-\%20ano\%20base\%202004.pdf (accessed on 10 September 2014). (In Portuguese)

18. Empresa de Pesquisa Energética (EPE)/ Ministério de Minas e Energia.(Brasil), Plano Nacional de Energia 2030. Empresa de Pesquisa Energética. Rio de Janeiro. 2007 government report http://www.mme.gov.br/mme/galerias/arquivos/publicacoes/pne_2030/PlanoNacionalDeEnergia2030. pdf (accessed on 10 September 2014). (In Portuguese)

19. Barletta, M.; Jaureguizar, A.J.; Baiguns, C.; Fountoura, N.F.; Agostinho, A.A.; Almeida-Val, V.M.F.; Val, A.L.; Torres, R.A.; Jimenez-Segura, L.F.; Giarrizzo, T.; et al. Fish and habitat aquatic conservation in South America: An overview with emphasis on Neotropical systems'. J. Fish Biol. 2010, 76, 2118-2176.

20. Instituto Humanitas Unisinos. Governo muda limites de unidades de preservação para viabilizar hidrelétricas, 2012. Available online: http://www.ihu.unisinos.br/noticias/510903-governo-mudalimites-de-unidades-de-preservacao-para-viabilizar-hidreletricas (accessed on 23 May 2014).

21. Castello, L.; MsGrath, D.G.; Hess, L.L.; Coe, M.T.; Lefevbre, P.A.; Petry, P.; Macedo, M.N.; Renó, V.F.; Arantes, C.C. The vulnerability of Amazon freshwater ecosystems. Conserv. Lett. 2013, 6, 217-219.

22. Rudd, J.W.M.; Harris, R.; Kelly, C.A.; Hecky, R.E. Are hydroelectric reservoirs significant sources of greenhouse gases? Ambio 1993, 22, 246-248.

23. Fearnside, P.M. Hydroeletric dams in the Brazilian Amazon as source of greenhouse gases. Environ. Conserv. 1995, 22, 7-19. 
24. Abril, G.F.; Guérin, F.; Richard, S.; Delmas, R.; Galy-Lacuax, C.; Gosse, P.; Tremblay, A.; Varfalvy, L.; Santos, M.A.; Matvienko, B. Carbon dioxide and methane emissions and the carbon budget of a 10-year old tropical reservoir (Petit Saut, French Guiana). Glob. Biochem. Cycles 2005, 19, 1-16.

25. Kemenes, A.; Forsberg, B.R.; Melack, J.M. Methane release below a tropical hydroelectric dam. Geophys. Res. Lett. 2007, 34, 12805-12809.

26. Fearnside, P.M. Greenhouse Gas Emissions from Land-Use Changes in Brazil's Amazon. In Global Climate Change and Tropical Ecosystems: Advances in Soil Science; Lal, R., Kimble, J.R., Stewart, B.A., Eds.; CRC Press: Boca Raton, FL, USA, 2000; pp. 231-249.

27. Cederberg, C.; Martin Persson, U.; Neovius, K.; Molander, S.; Clift, R. Including carbon emissions from deforestation in the carbon footprint of brazilian beef. Environ. Sci. Technol. 2011, 45, 1773-1779.

28. US Energy Information Agency, 2010. Brazil Overview Data. Available online: http://www.eia.gov/ countries/country-data.cfm?fips=BR (accessed on 1 August 2010).

29. Intergovernmental Panel on Climate Change (IPCC). Third Assessment Report: Climate Change 2001: Synthesis Report; ISBN: 978-0521015073; Cambridge University Press: Cambridge, UK, 2002. Available online: http://www.grida.no/publications/other/ipcc_tar/ (accessed on 23 May 2014).

30. Stern, N. Stern Review on the Economics of Climate Change (pre-publication edition). Executive Summary; HM Treasury: London, UK, 2006.

31. Medvigy, D.; Walko, R.L.; Avissar, R. Effects of deforestation on spatiotemporal distributions of precipitation in South America. J. Clim. 2011, 24, 2147-2163.

32. Marengo, J.A.; Soares, W.A.; Saulo, C.E.; Nicolini, M. Climatology of the low-level jet east of the Andes as derived from the NCEP-NCAR. Reanalyses: Characteristics and Temporal Variability. J. Clim. 2004, 17, 2261-2280.

33. Rosenberg, D.M.; Bodaly, R.A.; Usher, P.J. Environmental and social impacts of large scale hydroelectric development: Who is listening? Glob. Environ. Chang. 1995, 5, 127-148.

34. Lerer, L.B.; Scudder, T. Health impacts of large dams. Environ. Impact Assess. Rev. 1999, 19, 113-123.

35. McClain, M.E.; Naiman, R.J. Andean influences on the biogeochemistry and ecology of the Amazon River. BioSciences 2008, 58, 325-338.

36. Junk, W.J. The flood pulse concept of large rivers: Learning from the tropics. Arch. Hydrobiol. 1999, 11, 261-280.

37. Cushing, D.H. Plankton production and yearclass strength in fish populations-An update of the match-mismatch hypothesis. Adv. Mar. Biol. 1990, 26, 249-293.

38. Barthem, R.B.; Ribeiro, M.C.B.L.; Petrere, M. Life strategies of some long-distance migratory catfish in relation to hydroeletric dams in the Amazon Basin. Biol. Conserv. 1991, 55, 339-345.

39. Ribeiro, M.C.L.B.; Petrere, M.; Juras, A.A. Ecological integrity and fisheries ecology of the Araguaia-Tocantins River Basin, Brazil. Regul. Rivers Res. Manag. 1995, 11, 325-350.

40. Wearn, O.R.; Reuman, D.C.; Ewers, R.M. Extinction debt and windows of conservation opportunity in the brazilian amazon. Science 2012, 337, 228-232, doi:10.1126/science.1219013.

41. Rangel, T.F. Amazonian extinction debts. Science 2012, 337, 162-163, doi:10.1126/science.1224819.

42. Tilt, B.; Braun, Y.; He, D. Social impacts of large dam projects: A comparison of international case studies and implications for best pratices. J. Environ. Manag. 2009, 90, S249-S257. 
43. World Commission on Dams. Dams and Development a New Framework for Decision-Making: The Report of The World Commission on Dams; Earthscan Publications Ltd.: London, UK, 2000.

44. Petrere, M. Fisheries in large tropical reservoirs in South America. Lakes Reserv. Res. Manag. 1996, 2, 111-133.

45. Callède, J.; Guyot, J.P.; Ronchail, J.; L’Hôte, Y.; Niel, H.; Oliveira, E. Evolution du débit de l'Amazone à Óbidos de 1903 à 1999. Hydrol. Sci. J. Sci. Hydrol. 2004, 49, 85-97.

46. USNREL-US National Energy Research Laboratory. Energy Analysis: Utility Scale Energy Technology Capacity Factors, 2012. Available online: http://www.nrel.gov/analysis/tech_cap_ factor.html (accessed on 27 July 2012).

47. U.S Department of Energy. Revolution Now: The Future Arrives for Four Clean Energy Technologies, 2013. Available online: http://energy.gov/sites/prod/files/2013/09/f2/200130917-revolution-now.pdf (accessed on 5 July 2014).

48. ICF Consulting Ltd. Unit Costs of Constructing New Transmission Assets at $380 \mathrm{kV}$ within the European Union, Norway and Switzerland, 2002; Report prepared for the DG TREN/European Commission Study Contract NoTREN/CC/03-2002; IFC Consulting Limited: London, UK. Available online: http://ec.europa.eu/energy/electricity/publications/doc/comp_cost_380kV_en.pdf (accessed on 25 October 2013).

49. Lyons, C. The Dam Boom in the Amazon. The New York Times 2012. Available online: http://www. nytimes.com/2012/07/01/opinion/sunday/the-dam-boom-in-the-amazon.html (accessed on 30 June 2012).

50. Romero, S. Amid Brazil's Rush to Develop, Workers Resist. The New York Times 2012. Available online: http:/www.nytimes.com/2012/05/06/world/americas/brazilsrush-to-develophydroelectric-power-brings-unrest.html?ref=americas (accessed on 5 May 2012).

51. Pimenta, F.; Kempton, W.; Garvine, R. Combining meteorological stations and satellite data to evaluate the offshore wind power resource of Southeastern Brazil. Renew. Energy 2008, 33, 2375-2387.

52. Empresa de Pesquisa Energética, Análise da Inserção da Geração Solar na Matriz Elétrica Brasileira, NOTA TÉCNICA EPE: Rio de Janeiro, Brazil, 2012. (In Portuguese)

53. USDOE-US Department of Energy, 2011a. 2010 Solar Technologies Market Report; DOE-OG-102011-3318; USDOE: Washington, DC, USA, 2011. Available online: http://www.nrel.gov/docs/fy12osti/51847.pdf (accessed on 20 July 2013).

54. USDOE-US Department of Energy, 2010 Wind Technologies Market Report; DOE-GO-102011-3322; USDOE: Washington, DC, USA, 2011. Available online: http://www1.eere.energy.gov/wind/pdfs/51783.pdf (accessed on 20 July 2013).

55. Stickler, C.M.; Coe, M.T.; Costa, M.H.; Nepstad, D.C.; McGrath, D.G.; Dias, L.C.P.; Rodrigues, H.O.; Soares-Filho, B.S. Dependence of hydropower energy generation on forests in the Amazon Basin at local and regional scales. Proc. Natl. Acad. Sci. USA 2013, 110, 9601-9606, doi:10.1073/ pnas. 1215331110.

56. Pacala, S.; Socolow, R. Stabilization Wedges: Solving the climate problem for the next 50 years with current technologies. Science 2004, 305, 968-972, doi:10.1126/Scscience.1100103.

(C) 2014 by the authors; licensee MDPI, Basel, Switzerland. This article is an open access article distributed under the terms and conditions of the Creative Commons Attribution license (http://creativecommons.org/licenses/by/3.0/). 